\title{
The Role of Regional Public Library to Support Political Literacy in Society
}

\author{
Rahmat Setiawan Sefullah ${ }^{1}$, Tiyas Nur Haryani ${ }^{2}$ \\ ${ }^{1}$ Diploma Program in Library Science Faculty of Social and Political Sciences, Universitas Sebelas Maret \\ ${ }^{2}$ Public Administration Department Faculty of Social and Political Sciences, Universitas Sebelas Maret \\ rahmatsetiawans@staff.uns.ac.id, tiyasnurharyani@staff.uns.ac.id
}

Keywords: Library, regional public library, political literacy

\begin{abstract}
The Politics became currently used for the general public. Reform has generated a stream of freedom in public disclosure and disclosure as its supporters. This article discusses the role of regional libraries in strengthening the political literacy by the general public. Articles are reviewed through literature studies about the role from the regional library on political literacy. The results of literature studies indicate that regional library has a role in increasing community literacy. Regional Libraries can promote literacy training for the general public. Specialized corners of general election information can be provided at regional libraries so the general public can easily obtain information on aspects of the general election and election candidates' profiles in print and digital form.
\end{abstract}

\section{INTRODUCTION}

Indonesia is one of big democracy country after India and United states. The first democracy party in Indonesia did general election on 1995 after Republik Indonesia Independence. The general election is a mechanism selection header in staff formal politic (Darmawan, @2015). The first general election held to elect member of . Regional Representatives Council (DPRD), People's Representative Council (DPR), and Constituent Assembly. At that time, the constituent assembly was formed to draft the Constitution of the Republic of Indonesia (Badrun, 2016). The democratic party objective was political, social and economic changes through the elected candidate that will occupy the regime.

The development of general elections until the era of President Soeharto's administration or prereform era is considered not to give satisfaction to the public. Democratic practices in the Soeharto era were not considered democracy practice because freedom of information was limited to both media and readers (Burhan, 2016; Budiarjo, 2010). Postreform general elections judged to be better than the previous era because information disclosure and freedom of assembly and opinion have been guaranteed by the state for its people. In the 2004 general election the Indonesian people have also begun to elect directly their presidents and vice presidents, then followed by direct elections of provincial and district or city heads (Haris, 2015).

Perceive from the dynamics of democracy in Indonesia, increase the capacity of society in politics must be directly proportional to the democratic. The political participation of the community becomes an important element in democracy and as a form of people's sovereignty in government (Darmawan, 2015). The political participation of the Indonesian population in politics is relatively low. Data reported from the Election Commission of the Republic of Indonesia, the participation of the public in the Election is still at $70 \%$, among others, $72 \%$ in Election 2014, 74\% in elections 2017 and $73 \%$ in elections 2018 (KPU, 2018). The political participation of the community must be enhanced through the active role of stakeholders for success in the democrat party. Stakeholders have obligations in the implementation of political education, including political parties, central and regional electoral commissions, governments, political party elites, political candidates and mass media. The special is the political literacy capacity of the people in the post-truth era. The political literacy is knowledge, attitude, and practices from the community regarding politics including the holding of elections (Putri, 2017). Political literacy is best to enhance 
public participation in politics. Previous research conducted by Putri (2017) which examined political literacy on voters contained elaboration of variables in political literacy. First is political information variable which contained political candidate profiles, vision and work programs offered; second is search strategy variables; third is information provider.

As one of the government institutions, the local public library has a role to provide and manage so many information including information relating to politics. A collection of books relating to politics in the regional library is a source that can be used as a learning tool for the community in relation to political education. As a democratic country, the implementation of General Election in Indonesia is sometimes can be a problem with information that is not related to the candidate pairs both at the provincial and national level. The presence of social media is one of the causes of incorrect information "hoaxes". Related to the General Election in Indonesia information "hoax" is often created for political purposes with the aim of hitting political opponents. According to Monohevita (2017), the impact of information on hoaxes are politically charged can trigger disputes, commotion and insecurity in the community. Even worse, if it involves politics and racial intolerance, it can divide national unity. To anticipate the huge impact of hoax related to politics, libraries have a role to stop hoax information that has political content.

So far, the political literacy on political activity has been conducted by mass media and the General Election Commission. This study takes a position to see the role of regional libraries in strengthening the political literacy of the community. Studies on the role of regional libraries in political literacy are still minimally implemented by literature researchers. The role according to Thoha (2007) is an orderly sequence that deals with tasks and functions. Therefore, this article becomes interesting as the basic of the study.

\section{METHODS}

\subsection{Data Collecting}

This research is the result of a literature study. The data is constructed from the literature study of various literatures that refers to the keywords discussed. The literature used, among others, previous research in national journals, books and news clippings from the mass media.

\subsection{Interactive Functional Method}

Data analysis is done by using an interactive functional method, which stems from four activities namely data collection, data reduction, data presentation and data verification. The steps undertaken by the researchers are (1) Data collection is defined as a process of collecting data related to the keyword library. (2) Data reduction can be interpreted as the selection process, centralization, attention to simplification and transformation of raw data arising from written records in the field. (3) Presentation of data in this research is conducted to check, organize and classify data so as to produce descriptive data. (4) Verification is a goal in the field notes or conclusions of truth-tested data. Triangulation used is the triangulation of data.

\section{RESULTS AND DISCUSSIONS}

\subsection{Literacy Training to the Community}

Local public libraries should play a role in increasing the information literacy to the surrounding community this is also applies to political literacy. One of the purposes of public libraries by Sulistyo-Basuki (1993: 48), the library provides convenience fast access to the right information for the user. If we look at the purpose that is properly informed, as well as information about politics or ongoing general elections especially in the millennia era where information is growing so fast and abundantly. A lot of information contain hoax information, that is why regional libraries need to provide a program about information literacy to the society.

Literacy training by regional libraries needs to be done so that people can search, select and utilize the information properly and correctly. According to The Association for College and Research Libraries (ACRL) a literate information is able to:

- Determine the extent of information needed

- Access the needed information effectively and efficiently

- Evaluate information and its sources critically

- Incorporate selected information into one's knowledge base

- Use information effectively to accomplish a specific purpose

- Understand the economic, legal, and social issues surrounding the use of information, and access and use information ethically and legally 
Given the fact that there is still a lack of training on literacy given specifically to the community. The library as a provider of information resources should be able to provide literacy training. When people have literacy information they can easily find the sources of information they need and can select the information obtained. So that the community can solve problems related to the information needs and that is not less important is able to think critically related to the problems faced by both economic, social issues, and political problems.

\subsection{Special General Election Services}

The role of regional libraries to be able to provide an accurate source of information and from sources that can be trusted with the prospective head of the region so that it can be a reference for potential voters or political choice. (Buschman, 2017) The relationship between libraries and democracy is deeper and more complex than simply seeking information, seeking information, or efficacy in understanding and using information for decision making. From some research results, literacy have a role to determine the attitude of who will be elected in the election.

Currently there is no local public library in Indonesia that specifically welcomes the title of democracy party by providing information related to the election or candidate pairs. Although in fact it is really needed by the community so that people can determine the attitude of who will be selected. As Kadir says that (2014: 41) many decisions depend on the information.

The role of regional libraries in the title of democracy in Indonesia is actually needed, especially in relation to the source of information owned. Regional libraries should be able to provide literature related to the ongoing elections whether it is regional, provincial or national elections. The contribution of the local public libraries that can be provided in a democracy title is to provide special services in libraries relating to elections, such as providing election-specific services. In the service will contain information sources related to candidate pairs. The information in the special election language is information that has been filtered in truth before it is presented in the service. The information presented can be in the form of biographies candidate pair or clippings from a magazine or a newspaper that later processed into a source of information.

Not only in the form of printed source information that is in the special services of the General Election the library can also provide information in digital form in the special election services provided in the library to welcome the democratic party. Such as providing a source of information related candidate pairs in the form of videos that have been collected from various sites of video and television service providers that can be downloaded and then stored specifically to be utilized by the community. In the general election services in local public libraries, a list of eligible sources of information with general election information can be made available to the public. With the source of information general election test which is provided specifically in public libraries expected the public is no longer inedible by the political hoax news that is often deliberately raised and local public libraries can be data for the community in obtaining information related to the general election.

\section{CONCLUSIONS}

The role of public libraries in improving political literacy in Indonesia is needed. Moreover, the current information is growing so rapidly that it is difficult to determine the correct information and hoax. Thus, the training of information literacy in the local library is an effort that can be done so that the public can be information literate so as to select the information obtained. Creating special services general election that contain candidate information to the regions and candidates for election council members is also necessary because it can facilitate the public in obtaining election information. Some advantages if the literacy training activity and special election service successfully implemented in regional public library : 1) increase visit users to regional public library ,2) make regional public library reference to community to get information about the election, 3) Present a role to avoid hoax infomation about the election 4) incerase infromation collection about election.

\section{REFERENCES}

ACRL (The Association for College and Research Libraries). 2000. "Information Literacy Competency Standards for Higher Education" dalam http://www.ala.org/ala/mgrps/ divs/acrl/standards/informationliteracycompete ncy.cfm\#stan 
Badrun, Ubedilah. 2016. Sistem Politik Indonesia Kritik dan Solusi Sistem Politik Efektif. Jakarta: Bumi Aksara.

Budiarjo. 2010. Dasar-Dasar Ilmu Politik. Jakarta: Gramedia.

Buschman, J. (2017). Column: The Politics of Academic Librarianship: Academic Libraries, November 8, 2016 and Democracy. Journal of Academic Librarianship, 43(6), 548-549. https://doi.org/10.1016/j.acalib.2017.09.007

Darmawan, Ikhsan.2015. Mengenal Ilmu Politik. Jakarta: Gramedia

Haris, Syamsuddin. 2015. Dari Transisi ke Konsolidasi Demokrasi, dalam Subekti, 2015. Dinamika Konsolidasi Demokrasi. Jakarta: Yayasan Pustaka Obor Indonesia.

Kadir, Abdul. 2014. Pengenalan Sistem Informasi Edisi Revisi. Yogyakarta: CV. Andi Affset.

Monohevita, Lusiana. 2017. Stop Menyebarkan Hoax!. UI Lib berkala Vol. 3. No. 1 Tahun 2017

Putri, Nira Eka. 2017. Dampak Literasi Politik Terhadap Partisipasi Pemilih dalam PEMILU. Jurnal Agregasi Vol 5 No 1, 2017.

Thoha, Miftah. 2007. Pembinaan Organisasi (Proses Diagnosa dan Intervensi). Jakarta : PT. Raja Grafindo Persada. 